\title{
The institutional environment and the performance of private enterprises: population ecology and the institutional school revisited
}

\author{
Zongshi Chen ${ }^{1}$ and Lu Zheng ${ }^{2^{*}}$ (i)
}

* Correspondence:

I-zheng@tsinghua.edu.cn

Department of Sociology, Xiongzhixing Hall, Tsinghua University, Beijing 100084, China Full list of author information is available at the end of the article

\begin{abstract}
Combining the perspectives of population ecology and the institutional school, this article examines the influence of private sector development on the performances of private enterprises in different provinces of China. The analysis shows that rapid growth of the private sector has a negative impact on the performance of private enterprises in provinces with a well-developed private sector, whereas it has a positive impact on private firm performance in provinces with a less-developed private sector. We argue that the former finding is largely due to the competitive mechanism in firms' environment, and the latter to the legitimacy mechanism. Further analysis also shows that young and small private enterprises benefit more in a rapidly growing private sector. In doing so, this article contributes to population ecology theoretically and methodologically; it also qualifies "the liability of newness."
\end{abstract}

Keywords: Population ecology, Institutional school, Legitimacy mechanism, Competitive mechanism, Private sector development, Performance of private enterprises

\section{Background}

One of the core assumptions in organizational sociology is that organizational environment is vague and ever changing (Fligstein and Dauter 2007; Zhou 2003). Related research in population ecology focuses on the influence of the technical environment on organizational form and survival rate (Hannan and Freeman 1977; Haveman and Rao 1997), while the institutional school explores how institutional factors, such as social norms, recognition, and legitimacy, shape the structure and behaviors of organizations (Meyer and Scott 1983; DiMaggio and Powell 1983; Gao 2008; Guo et al. 2007). Such research either observes one organizational form for a long time to explore how it evolves or examines how organizations form their structure and behave under institutional constraints. Little attention has been paid to the relationship between the speed of institutional change and firm performance. On the other front, organizational scholars studying transition economies examine the relationship between institutions and firm performance mainly through two angles. One focuses on organizational efforts in overcoming institutional obstacles; the other compares firm performance

(C) 2015 Chen and Zheng. Open Access This article is distributed under the terms of the Creative Commons Attribution 4.0 International License (http://creativecommons.org/licenses/by/4.0/), which permits unrestricted use, distribution, and reproduction in any medium, provided you give appropriate credit to the original author(s) and the source, provide a link to the Creative Commons license, and indicate if changes were made. 
under different institutional environments. This article explores how the speed of institutional change affects firm performance. The institutional environment can be stable or transitional, changing at a slow or fast pace (Roland 2004). Different speeds of change can affect firm performance, and this influence may vary across industry sectors and regions. Previous research has shown that the institutional environment influences performances of firms and well-developed market conditions improve firm performance (Xin \& Pearce 1996; Peng 2000; Nee 1992; Li et al. 2008). The existing literature mostly focuses on the comparison of static institutions; however, it overlooks how the changing institutional environments affect the performance of enterprises. For example, institutions with a low but fast-growing level of marketization may be more helpful to the performance of enterprises than those with a high but stable level of marketization. Thus, the static comparisons in previous research have failed to explicate the effect of changing environments on enterprises' performance. Zhou and Zhao (2009) point out that Chinese social sciences are still poor in applying organization theories and models in the study of organizations and the dialog with organization studies in the West. This paper combines the perspectives of population ecology and the institutional school and explores how the developmental pace of private economy across Chinese provinces impacts the performance of private enterprises.

\section{Population ecology}

According to population ecology, organizations in new forms have high death rates and low survival rates in the early stage because of the small number of organizations and hence the low level of legitimacy. As the number of new organizations grows, the legitimacy of new organizations gradually increases, which enhances the survival rate and decreases the mortality rate of organizations. However, as the number of organization crosses a threshold, the legitimacy mechanism is replaced by the competition mechanism since organizations do not have to worry about legitimacy. On the contrary, the increasingly intensive competition for resources and markets due to the growing number of organizations results in the rise of the mortality rate and the decline of an organization's chances for survival (Hannan and Freeman 1977). Hannan and Freeman (1987) find that the founding rates of American labor unions from 1836 to 1985 formed an inverted U-shaped curve, while the dissolution rates fit a U-shaped curve (Hannan and Freeman 1988). According to Carroll and Delacroix (1982), the newspaper industries in Argentina (1800-1900) and Ireland (1800-1970) both have U-shaped death rates and inverted U-shaped survival rates.

As one of the major schools in sociology, population ecology has particular contributions and insights, but there are still some deficiencies. First, most of the studies in this field apply event history analysis to examine the survival, founding, and death rates of organizations, but little attention has been paid to organizational performance (Carroll and Delacroix 1982; Freeman et al. 1983; Hannan 2005; Hannan \& Freeman 1987, 1988; Tucker et al. 1984). The only exception here is Carroll and Huo's work (1986) on the influence of institutional factors on newspaper circulation. In this paper, institutional environment variables include economic peak and trough years, industrial establishments, presidential election years, and political turmoil; among which, only political turmoil is influential in the way that it affects the founding and death of newspapers and has little impact on newspaper circulation. 
Second, most studies in population ecology focus on the long-term pattern of an organization form under a particular social and institutional environment, but relatively less attention has been paid to regional differences within the same society. Classic works by Hannan (2005) and others consider the country to be the boundary of competition for organizations, while Zuker (1989) points out that organizations may compete for resources in smaller regions. Some scholars are also aware of the complex effects of regional resources and the environment on organizations (Carroll and Wade 1991; Hannan and Carroll 1992; Lomi 1995). For example, Baum and Mezias find that in Manhattan, the stronger the local competition for size, price, and location, the higher the death rates of hotels. Lomi (1995) documents that from 1964 to 1988, differences existed across 13 regions in Italy in terms of the competition and legitimacy mechanisms among rural cooperative banks. However, regional comparative studies are rare in population ecology and are limited to a single industry.

A distinguishing feature of population ecology is the analysis of organizational density, measured by the number of organizations through event history analysis (Hannan 2005). Because of its methodology, it is hard for population ecology to break through after the rapid development from the late 1970s to the 1990s. However, the density of an organization can only reflect the environment within the population; such measurement is too narrow since it considers organizational survival and competition to be confined within the population (often within an industry in empirical research), but ignores the competition between different forms of organizations (Zucker 1989). In line with Zucker, we argue that it is problematic to use the number of organizations to measure organizational density because it lacks comparison with other forms of organizations. For example, an increase by a small number for a certain organization in a very small economy and slowly developing society or region may imply significantly improvement in legitimacy; however, such an increase in a large economy and rapidly developing society or region may not imply an improvement in legitimacy as opposed to other organizational forms, particularly rival forms. We therefore propose that organizational density should be measured by the proportion of certain types of organizations scaled by the total economy. This method better captures the competition between different forms of organizations.

\section{The institutional school and population ecology revisited}

The institutional school and population ecology arose at almost the same time. The institutional school focuses on social norms, standards, cognition, and culture, while population ecology pays more attention to the technical environment. Each of the two schools has absorbed merits from and critiqued the other (Baum and Powell 1995; Carroll and Huo 1986). Legitimacy, which has been widely discussed in both schools, is treated as an important institutional factor in the institutional school (Liu and Tian 2009; Yang 2011), and most studies examine how different kinds of legitimacy influence organizations. However, legitimacy is considered a technical factor that is a function of organization density in population ecology, and scholars have mainly focused on how organizational density affects the survival or death of organizations. Moreover, researchers in the institutional school believe that legitimacy in population ecology is cognitive legitimacy that ignores the support from the external environment, which is 
known as sociopolitical legitimacy (Baum and Powell 1995; Singh et al. 1986; Suchman 1995; Zimmerman and Zeitz 2002). Zucker (1989) points out that population ecology also lacks a proper measurement of legitimacy and obtrusively treats organization density as equivalent to legitimacy. Baum and Powell (1995) further critique that population ecology has conflated organizational density with legitimacy in the sense that the former appears to be the proxy but also as the process for the latter. In addition, institutional theorists argue that historical contexts are vital for organizational legitimacy, and therefore, population ecology has the problem of ahistoricism due to its lack of social contexts (Zucker 1989; Baum and Powell 1995).

The existing literature in the institutional school focuses on the causes and mechanisms for institutional changes and how these changes shape organizations' structures and behaviors. A more macro analysis of institutional change examines political and economic change at national level. For example, China's gradual transition is considered to be more successful than the "shock therapy" in the former Soviet Union and Eastern Europe. Scholars have noted the pace of institutional change; Roland proposes the classification of institutions into "slow-moving" and "fast-moving" institutions (Roland 2004). However, it is still unclear how the changing pace of institutions influences organizations' performance and behavior.

This paper applies the concepts and mechanisms in population ecology to explore how the changing pace of institutions affects organizational performance. First, we argue that organizational density, measured by the proportion of market share, employment, and investment in the total economy, reflects the developmental level of this type of organization as well as its cognitive legitimacy, which is also an important institutional factor. Caroll and Huo (1986) argue that the institutional environment includes not only rules and beliefs but also market size, shape, condition, and stability. Therefore, organizational density is a good measurement of the developmental level and institutional environment of organizations. The pace of change in organizational density during a certain period reflects the process of legitimacy, that is, the changing pace of the institutional environment. When organizational density or the level of organizational development is low, the legitimacy mechanism determines organizational performance and rapid development of organizational density is beneficial. When organizational density is high, which indicates a high level of organizational development, the legitimacy mechanism is replaced by competition mechanism, and the rapid development of organizational density is harmful to organizational performance. Second, though population ecology theorists usually contend that competitive environments are country specific, some acknowledge that institutional environments may be different across regions within a country. Carroll and Huo (1986) argue that institutional factors such as market size, shape, and condition may vary across regions, and such variation may influence organization behavior. Therefore, for a certain type of organization, its developmental level and legitimacy and the competitive environment may be different in different regions of the same country. The legitimacy mechanism dominates in regions with low organizational density, whereas the competition mechanism dominates in places with high organizational density. Finally, social and historical contexts should be taken into account in the analysis of organizations' institutional environment since the legitimacy of organizations comes partially from sociopolitical support. 
Drawing on the theoretical framework discussed previously, our paper explores how the developmental level and pace of the private economy affect private enterprises' performance. In addition, this paper further explores the interaction effects between the fast-changing pace and corporate characteristics, including firm size and firm age.

\section{The development of private sectors and regional development in China}

One of the most important factors in the development of the Chinese private economy is legitimacy. In the socialist movement in the 1950s, the private economy was completely nationalized due to socialist ideology. The private economy was long regarded as the symbol of capitalism that had to be eliminated in China. In the early stage of reform, the relatively open policy on the coast allowed the revival of private enterprise. Private enterprises could not register as private entities but instead had to register under other public entities, which is known as wearing a "red hat" for the sake of legitimacy. China's first legislation on private enterprises, the Provisional Regulation of Wenzhou Private Enterprises, was passed in Wenzhou, Zhejiang, in 1987. Drawing on the practice in Wenzhou, in 1988, the National People's Congress promulgated the Provisional Regulation of Private Enterprises, which legitimized the existence of private enterprises throughout the country. The 14th Chinese Communist Party (CCP hereafter) Congress further assured the legal status of private enterprises in 1992. Then in the 16th CCP Congress, private enterprise owners were allowed to join the CCP, which was viewed as a major step in enhancing the legitimacy of the private economy. However, private enterprises today still suffer from discrimination in industry entry, financing, and many other aspects and have to seek support through social networks or political connections ( $\mathrm{Li}$ et al. 2008; Peng 2000). These issues indicate the vital importance of legitimacy for the development of private enterprises.

The historical development of private enterprises is a step development across regions in China. Coastal areas enjoyed rapid development of the private economy in the 1980s and 1990s due to increased autonomy in policies. Since the middle of the 1990s, the Chinese government has provided more support for inland areas, such as the projects of the "Great Western Expansion" in 1999, the "Northeast Revitalization" in 2003, and the "Rise of Central China" in 2005. To attract coastal private enterprises, the middle and western regions provided more favorable policies on taxes, finance, and land use than the coastal regions did. In contrast, after about two decades of rapid development, the coastal private enterprises decreasingly contributed to the coastal economy due to their relatively smaller size and more investment of labor and land but less added value. The GDP-oriented coastal governments increasingly provided more support for large and capital-intensive enterprises, while the local private enterprises experienced more and more difficulty in obtaining capital and land. This policy is known as "vacating the cage to change birds" (teng long huan niao). Since 2000, this policy has been implemented to some degree in many coastal provinces (Zheng and Tong 2010). In the last 10 years, a large number of private enterprises have moved from regions with an advanced private economy to those with a relatively backward private economy. For example, the garment industry in the southeast moved to Henan, the footwear industry moved from Wenzhou to Chongqing, and glasses businesses moved from Wenzhou to Jiangxi. 
Many studies in spatial economics used data from before 2002, and their findings suggest that the development of the private economy in the coastal regions is much better than that in the inner provinces (Fan and Sun 2008). However, recent research has shown that the gap between coastal and inland areas has declined since 2004 (Fan and Sun 2008; $\mathrm{Xu}$ and Li 2006; Chan and Wang 2008). The dynamic development of China's private economy across regions provides a good opportunity to explore the causes and mechanisms in China's economy transition and to test the hypotheses presented below.

\section{Hypotheses}

The developmental pace of private sectors and the performance of private enterprises

According to population ecology, the death rate is high for new organizations in the initial stage due to their small number or density and low legitimacy in the market. As the number of organization increases, their legitimacy will improve. Consequently, the mortality rates will decrease, and the survival rates and founding rates will rise. However, when the organizational number or density crosses a threshold, the legitimacy mechanism will be replaced by the competition mechanism, that is, the growing number of organizations will intensify the competition for resources and markets and will thus impede founding rates and lead to a rise in death rates.

We incorporated population ecology into the institutional analysis and offer the following propositions: when organizational density is low, the rapid development of organizations is beneficial for organizational performance driven by the legitimacy mechanism; and when organizational density is high, the rapid development of organizations is harmful for organizational performance driven by the competition mechanism. Some studies of population ecology show that the mechanisms of competition and legitimacy vary across regions (Baum and Mezias 1992; Lomi 1995). We therefore argue that in provinces with a relatively advanced private economy, the legitimacy of private enterprises is high. The competition mechanism thus determines the development of private enterprises, and the growth of the private economy will inhibit the performance of private enterprises. In contrast, the legitimacy mechanism dominates in provinces with a relatively backward private economy. The rapid development of private enterprises means the improvement of legitimacy; more importantly, legitimacy also comes partially from governmental support, which is helpful for private enterprises in obtaining resources, expanding markets, and consequently improving performance. Thus, we can draw the following hypothesis:

Hypothesis 1: The rapid development of the private economy has a negative effect on the performance of private enterprises in provinces with a high level of private economy and a positive effect on the performance of those in provinces with a low level of private economy.

\section{The developmental pace of private sectors: firm size and performance of private enterprises}

The existing literature shows that large enterprises show better performance because their diversification, scale economy, and formal procedures make operations and management more effective (Penrose 1995). Opponents argue that the size of an enterprise has something to do with market power (Shepherd 1986), and increase of market power will grow X-inefficiency (Leibenstein 1976). That is, when the market power of a large enterprise grows into a monopoly, the loose management will discourage innovation and consequently decrease efficiency. Most of these studies focus on stable environments. 
Population ecology offers a different perspective and argues that the growth of organizational size will increase structural inertia, which will result in the organization's slow adaptation to the environment. Generally speaking, structural inertia is high for large enterprises due to their large size, standard routines, stability, and reliability (Hannan and Freeman 1984). In contrast, small enterprises are less constrained by structural inertia (Miller et al. 1982). Studies also document that small enterprises benefit more in turbulent environments than in stable environments (Covin and Slevin 1989), and the innovation strategy has a stronger positive effect on small enterprises in turbulent environments. We argue that small enterprises show better performance in fastchanging environments due to their lower level of structural inertia and more flexible adaptation in product and market strategy; in contrast, large enterprises find it more difficult to adapt to fast-changing environments, constrained by their structural inertia and high cost of coordination among various departments. We thus draw the following hypothesis:

Hypothesis 2: The rapid development of the private economy is more beneficial to the performance of small private enterprises than that of large enterprises.

\section{The developmental pace of private sectors: age and performance of private enterprises}

Stinchcombe (1965) argues that new organizations suffer from the "liability of newness" because they have to learn new roles as social actors and coordinate new roles of employees and their legitimacy is low. New organizations tend to lose the competition with existing organizations and have high death rates, while old enterprises gain their advantage from stability and reliability (Hannan and Freeman 1984). Numerous studies reveal the negative relationship between firm age and firm's mortality rates. For example, Freeman et al. (1983) document that labor unions and the semi-conductor industry have some degree of the liability of newness. Carroll and Delacroix (1982) find that older newspapers are less likely to die; Carroll (1985) points out that liability of newness also exists in the retail, wholesale, and manufacturing industries. However, Singh et al. (1986) offers a different perspective, arguing that the liability of newness is due less to the need for internal coordination within new organizations but more to the lack of institutional support. Their research on volunteer organizations in Toronto (1970-1980) demonstrates that most internal changes are unrelated to death rates except for a change in $\mathrm{CEO}$, whereas external legitimacy significantly depresses mortality rates. The effect of external legitimacy is measured by the acquisition of a community directory listing, the acquisition of a charitable registration number, and board size at birth, and their findings suggest that institutional support can make up for the liability of newness. In addition, some studies show that owing to inertia and petrifaction, old enterprises lack the flexibility to adapt to the fast-changing market and thus have poorer performance than new enterprises (Marshall 1920).

When the private economy grows rapidly, this leads to better institutional support for private enterprises, which can offset the effect of the liability of newness. Meanwhile, the flexibility of new enterprises leads them to adapt to rapid changes in the market. We therefore draw the following hypothesis:

Hypothesis 3: Rapid development of the private economy is more beneficial to the performance of new private enterprises than that of old private enterprises. 


\section{Methods}

\section{Sample and data source}

The data in this study comes from the 2008 national survey of private enterprises, which was carried out by the United Front Work Department of the Communist Party of China Central Committee, the All-China Federation of Industry and Commerce, the State Administration for Industry and Commerce, and the China Private Economy Research Institute. This survey covers private enterprises from 31 provinces in China across industries, stages, and sizes. The sample has 1607 observations with complete information after the deletion of missing values.

\section{Variables and models}

The dependent variable in this paper is the performance of private enterprises. We used ROE, return on equity, to measure an enterprise's performance. The logarithm of ROE is used in the regression model due to the skewed distribution of ROE. We also used ROA, return on assets, to perform the robustness test.

The major independent variable in this paper is the developmental pace of the private economy, in other words, the growth rate of the private economy's density. Our previous discussion shows that measuring organizational density through the number of organizations results in bias. Zucker critiques Hannan and Carroll's measurement (1989) and argues that "newspapers may at one stage be competing within population (with other newspapers), but at a later stage be competing for both consumers and advertisers with radio, news magazines, and television news, none of which is entered into density as measured by Carroll and Hannan" (Zucker 1989, 543). It is therefore more appropriate to use the proportion of the population scaled by the total economy, including rival populations. For example, in many sectors, Chinese private enterprises also compete with state-owned enterprises, collective-owned enterprises, and foreign enterprises. China's economy has grown rapidly and now ranks second in the world; the proportion of the private economy in the national economy as the measurement of the density or development level of private economy will thus better capture the relationship between the density and legitimacy of private economy. Unlike private enterprises in the West, in China, legitimacy is vital for the survival and development of private enterprises (Ahlstrom and Bruton 2001). Furthermore, the measurement of organizational density in our paper is province specific, based on the following rationalities. First, our method is inspired by the few studies on organizational competition driven by regional density (Baum and Mezias 1992; Lomi 1995). Second, scholars have extensively explored the local protectionism across provinces in China and found that local protectionism is rampant and interprovincial trade barriers are severe (Zhou Zhou 2004; Young 2000; Bai et al. 2004). According to Sandra Poncet, a French economist, "the average tariff between Chinese provinces is higher than that between the states in European Union, and the number of local goods purchased by Chinese consumers is 21 times that of goods made in other provinces" (Hu and Zhang 2005, 103). This clearly indicates that the competition between economic organizations mainly occurs within the provincial boundary.

First, we created a development index of the private economy. We partially borrowed methods from other scholars (Fan et al. 2010; Li et al. 2008); selected the three 
dimensions of investments, sales, and urban employment from the China's Statistics Yearbooks from 2006 to 2008; and then calculated the proportion of the private economy within the total economy. The development index of the private economy is the arithmetic average of the three proportions.

Second, we used the percentage of the developmental index in 2007 divided by that in 2006 to measure the developmental pace of the private economy. We further used the median of the developmental pace and classified the country into fast-growing and slow-growing regions. The developmental indexes and growth rates in 2006 and 2007 are shown in Table $1{ }^{1}{ }^{1}$

Provinces with a high level of private economy such as Jiangsu, Shandong, or Guangdong have a much slower growth rate than provinces with a lower level. Shanghai, Tianjin, and Beijing actually have a negative growth rate, while Yunnan, Gansu, Anhui, Neimenggu, and Chongqing, where the private economy is at a relatively low level, rank at the top in growth rate. We also adopted continuous growth rate in the analysis, and the results are consistent with those of the dummy variable of growth rate.

We therefore used the following equation to test our hypotheses:

Private enerprise performance $=\beta_{0}+\beta_{1}$ growth rate $+\beta_{2}$ growth rate

$\times$ development index $+X \delta+\varepsilon$

In addition, we also investigated the influence of the size and age of an enterprise on its performance. We took the logarithm of the number of employees by the end of 2006 to measure enterprise size, while enterprise age is calculated from the founding year to 2007. All enterprises in the sample were registered in 2006 or before.

Table 1 Developmental indexes and growth rates for private economy in 2006 and 2007

\begin{tabular}{lllllllr}
\hline Province & 2006 & 2007 & Speed & Province & 2006 & 2007 & Speed \\
\hline Yunnan & 15.80 & 19.07 & 20.73 & Hebei & 18.98 & 20.62 & 8.66 \\
Gansu & 12.02 & 14.05 & 16.87 & Shaanxi & 9.61 & 10.41 & 8.33 \\
Hainan & 21.04 & 24.46 & 16.23 & Jiangxi & 24.13 & 26.12 & 8.22 \\
Anhui & 20.18 & 23.36 & 15.76 & Jiangsu & 35.08 & 37.86 & 7.93 \\
Chongqing & 21.79 & 25.12 & 15.27 & Shandong & 25.59 & 27.62 & 7.90 \\
Neimenggu & 15.81 & 18.16 & 14.88 & Sichuan & 17.33 & 18.52 & 6.87 \\
Zhejiang & 23.08 & 26.26 & 13.79 & Guangxi & 16.48 & 17.58 & 6.71 \\
Henan & 17.51 & 19.85 & 13.37 & Shanxi & 14.45 & 15.32 & 6.06 \\
Heilongjiang & 12.91 & 14.63 & 13.30 & Ningxia & 16.51 & 17.32 & 4.90 \\
Fujian & 23.54 & 26.55 & 12.79 & Xinjiang & 10.69 & 11.18 & 4.62 \\
Tibet & 13.43 & 15.12 & 12.58 & Hunan & 18.81 & 19.55 & 3.95 \\
Jilin & 13.92 & 15.53 & 11.64 & Qinghai & 20.63 & 21.04 & 1.94 \\
Liaoning & 19.52 & 21.76 & 11.49 & Shanghai & 28.42 & 27.75 & -2.36 \\
Hubei & 20.57 & 22.84 & 11.01 & Tianjin & 19.33 & 18.70 & -3.28 \\
Guizhou & 16.57 & 18.28 & 10.30 & Beijing & 13.78 & 13.15 & -4.54 \\
Guangdong & 22.19 & 24.44 & 10.14 & & & & \\
\hline
\end{tabular}


We used Eq. (2) to analyze the interactive effect between enterprise size and the growth rate of private economy and Eq. (3) for the interactive effect between enterprise age and the growth rate.

$$
\begin{aligned}
\text { Private enerprise performance }=\beta_{0} & +\beta_{1} \times \text { growth rate }+\beta_{2} \text { fast growth } \\
& \times \text { size }+X \delta+\varepsilon .
\end{aligned}
$$

Private enerprise performance $=\beta_{0}+\beta_{1} \times$ growth rate $+\beta_{2}$ fast growth

$$
\times \text { age }+X \delta+\varepsilon \text {. }
$$

Finally, our models controlled several sets of variables. The first is corporate variables, including industry, assets (log-transformed), leverage, and the size of management. The second set is individual variables, including age, gender, education, and CCP membership ( $\mathrm{Li}$ 1998) of private entrepreneurs. The last is the provincial economic development measured by GDP (log-transformed). The data originally classified the industry into nineteen industries; however, since the number of enterprises in some of the industries is too small, we classified the industries into six groups: (1) agriculture and mining; (2) manufacturing and electric power; (3) construction and transportation; (4) information, technology, finance, and real estate; (5) sales; and (6) other industries. After the reclassification, each group had more than 100 enterprises, as shown in Table 2.

Table 2 Summary of statistics of key variables

\begin{tabular}{llllll}
\hline Variables & Obs. & Average & SD & Min & Max \\
\hline ROE & 1607 & 0.424 & 1.407 & 0 & 26.75 \\
ROE (log) & 1607 & -2.151 & 1.55 & -8.78 & 3.287 \\
Total assets (10,000) & 1607 & 2791.747 & 9091.0 .236 & 2 & 205,000 \\
Total assets (log) & 1607 & 6.319 & 1.879 & 0.693 & 12.231 \\
Enterprise size & 1607 & 207.512 & 573.863 & 2 & 12,000 \\
Enterprise size (log) & 1607 & 4.142 & 1.515 & 0.693 & 9.393 \\
Financial leverage & 1607 & 0.240 & 0.262 & 0 & 0.993 \\
Enterprise age (year) & 1607 & 7.828 & 4.782 & 1 & 27 \\
Management size & 1607 & 0.163 & 0.105 & 0.01 & 0.5 \\
Industry & & & & & 1 \\
$\quad$ Agriculture and mining & 1607 & 0.090 & 0.286 & 0 & 1 \\
$\quad$ Manufacture and power & 1607 & 0.496 & 0.500 & 0 & 1 \\
$\quad$ Construction and transportation & 1607 & 0.094 & 0.292 & 0 & 1 \\
$\quad$ Information, finance, and real estate & 1607 & 0.063 & 0.244 & 0 & 1 \\
$\quad$ Sales & 1607 & 0.166 & 0.372 & 0 & 1 \\
Male & 1607 & 0.856 & 0.351 & 0 & 1 \\
Age & 1607 & 44.803 & 8.234 & 18 & 79 \\
Education level (year) & 1607 & 14.210 & 2.799 & 6 & 19 \\
CCP membership & 1607 & 0.366 & 0.482 & 0 & 1 \\
\hline
\end{tabular}




\section{Results}

The mean of ROE was 0.42, private enterprises hire 207 employees on average, the average proportion of management within all employees was $16.3 \%$, and the average age of all enterprises in 2007 was 7.8 years. Males composed $85.6 \%$ of all business owners, and $36.6 \%$ were CCP members. The average age of business owners was 45 years old, while the average education was 14 years.

According to Table 3, the correlation coefficient between the main variables is below 0.3 , and the VIF in the regression model with no interaction terms is 1.78 ; this indicates no multicollinearity problem, and it is thus appropriate to use OLS regression. ${ }^{2}$

Model 1 in Table 4, which contains no interactive effects, shows that the developmental index of private economy in 1 year (2006) has a significant positive effect on the performance of private enterprises in the following year (2007), while the growth rate of private economy has no influence on the performance of private firms. A high level of private economy development in a province thus promotes the performance of local private enterprises, and the increasing pace has nothing to do with the performance of private firms.

Model 2 focuses on the interaction between the level of private economic development and the growth rate. Rapid growth in private economy clearly has a negative impact on the performance of private enterprises in provinces with a high level of private economy, and the effect is highly significant. This indicates that competition is intensive in provinces with a high level of private economy, and further development will inhibit the performance of private enterprise. In contrast, in regions with a less-developed private economy, the rise of the proportion of investments, sales, and employment in the private economy enhances the cognitive legitimacy of private enterprises; such growth is also supported by governmental policies, which implies the rise of sociopolitical legitimacy. Both are beneficial for the performance of private enterprises. The results lend support to hypothesis 1 . Models 3 and 4 examine the influence of enterprise size and age on the performance of private enterprises. The data in model 3 demonstrates the positive effect of enterprise size on enterprise performance; however, large size is found to be detrimental to performance of enterprises when the private economy is growing rapidly, and the negative effect is statistically significant $(p<0.05)$. The results support hypothesis 2 , that is, the advantage of a large scale is weakened in a rapidly changing economy. The results in model 4 reveal that enterprise age has a positive effect on enterprise performance, but the effect is negative in rapidly changing environments. The results lend support to hypothesis 3 , that is, the advantage of old enterprises is weakened in fast-changing institutions. This implies that regions where the private economy grows rapidly provide more support for private enterprises; new private enterprises have better institutional support, which helps them overcome the liability of newness. In addition, new enterprises are more flexible than old enterprises; therefore, fast-changing institutions are more beneficial to new enterprises.

We next report the results of control variables. The effect of assets on enterprise performance is significantly negative, but the effects of management size and leverage are significantly positive in all models. In terms of industry, the groups of mining/agriculture and information/finance/real estate are higher than other industry groups; there is no discernible difference among the other four industry groups. As to individual characteristics, the effect of education is significantly positive, and the results are almost consistent with the findings in the literature. CCP membership is found to have 
Table 3 Pearson correlation of key variables

\begin{tabular}{|c|c|c|c|c|c|c|c|c|c|c|}
\hline & ROE (log) & Asset (log) & Enterprise size (log) & Leverage & Enterprise age & Management size & Male & Age & Education & $\mathrm{CCP}$ \\
\hline ROE (log) & 1.00 & & & & & & & & & \\
\hline Asset (log) & -0.16 & 1.00 & & & & & & & & \\
\hline Enterprise size (log) & 0.09 & 0.71 & 1.00 & & & & & & & \\
\hline Leverage & 0.20 & 0.29 & 0.24 & 1.00 & & & & & & \\
\hline Enterprise age & -0.03 & 0.20 & 0.18 & 0.02 & 1.00 & & & & & \\
\hline Management size & 0.00 & -0.26 & -0.54 & -0.07 & -0.13 & 1.00 & & & & \\
\hline Male & 0.03 & 0.13 & 0.15 & 0.07 & 0.08 & -0.08 & 1.00 & & & \\
\hline Age & -0.08 & 0.14 & 0.15 & 0.04 & 0.24 & -0.11 & 0.09 & 1.00 & & \\
\hline Education & 0.05 & 0.23 & 0.18 & -0.03 & -0.07 & 0.06 & 0.02 & -0.22 & 1.00 & \\
\hline CCP & -0.04 & 0.21 & 0.23 & 0.09 & -0.02 & -0.09 & 0.14 & 0.23 & 0.11 & 1.00 \\
\hline
\end{tabular}


Table 4 Growth rate of private economy and performance of private enterprises

\begin{tabular}{|c|c|c|c|c|c|c|c|c|}
\hline & $\begin{array}{l}\text { Model } 1 \\
\text { Coefficient }\end{array}$ & SE & $\begin{array}{l}\text { Model } 2 \\
\text { Coefficient }\end{array}$ & SE & $\begin{array}{l}\text { Model } 3 \\
\text { Coefficient }\end{array}$ & SE & $\begin{array}{l}\text { Model } 4 \\
\text { Coefficient }\end{array}$ & SE \\
\hline \multicolumn{9}{|l|}{ ROE (log) } \\
\hline Asset (log) & $-0.471^{* * * *}$ & 0.028 & $-0.468^{* * * *}$ & 0.028 & $-0.472^{* * * *}$ & 0.028 & $-0.468^{* * * *}$ & 0.028 \\
\hline Enterprise size (log) & $0.490^{* * * *}$ & 0.040 & $0.490^{* * * *}$ & 0.039 & $0.530^{* * * *}$ & 0.044 & $0.487^{* * * *}$ & 0.039 \\
\hline Leverage & $1.561^{* * * *}$ & 0.141 & $1.573^{* * * *}$ & 0.141 & $1.561^{* * * *}$ & 0.141 & $1.552^{* * * *}$ & 0.141 \\
\hline Enterprise age & 0.005 & 0.008 & 0.006 & 0.008 & 0.005 & 0.008 & $0.322^{* * * *}$ & 0.095 \\
\hline Management size & $1.629^{* * * *}$ & 0.407 & $1.601^{* * * *}$ & 0.406 & $1.588^{* * * *}$ & 0.407 & $1.605^{* * * *}$ & 0.406 \\
\hline \multicolumn{9}{|l|}{ Industry } \\
\hline Agriculture and mining & $0.472^{* * *}$ & 0.166 & $0.443^{* * *}$ & 0.166 & $0.471^{* * *}$ & 0.166 & $0.508^{* * *}$ & 0.166 \\
\hline Manufacture \& power & 0.017 & 0.129 & -0.003 & 0.129 & 0.009 & 0.129 & 0.014 & 0.129 \\
\hline $\begin{array}{l}\text { Construction and } \\
\text { transportation }\end{array}$ & 0.046 & 0.163 & 0.040 & 0.163 & 0.030 & 0.163 & 0.046 & 0.163 \\
\hline $\begin{array}{l}\text { Information, technology, } \\
\text { real estate, and finance }\end{array}$ & $0.400^{* *}$ & 0.183 & $0.391^{* *}$ & 0.182 & $0.408^{* *}$ & 0.182 & $0.387^{* *}$ & 0.182 \\
\hline Sales & -0.038 & 0.145 & -0.060 & 0.144 & -0.040 & 0.145 & -0.030 & 0.144 \\
\hline Male & 0.094 & 0.102 & 0.087 & 0.102 & 0.099 & 0.102 & 0.088 & 0.102 \\
\hline Age & $-0.009 \#$ & 0.005 & $-0.009^{* *}$ & 0.005 & $-0.009 \#$ & 0.005 & $-0.009^{* *}$ & 0.005 \\
\hline Education & $0.045^{* * * *}$ & 0.014 & $0.045^{* * * *}$ & 0.014 & $0.044^{* * * *}$ & 0.014 & $0.042^{* * *}$ & 0.014 \\
\hline CCP & $-0.176^{* *}$ & 0.078 & $-0.167^{* *}$ & 0.077 & $-0.175^{* *}$ & 0.078 & $-0.158^{* *}$ & 0.078 \\
\hline Provincial GDP (log) & 0.014 & 0.060 & -0.082 & 0.067 & 0.018 & 0.060 & 0.013 & 0.060 \\
\hline $\begin{array}{l}\text { Development index of private } \\
\text { economy in } 2006\end{array}$ & $1.734^{* *}$ & 0.687 & $2.329^{* * * *}$ & 0.709 & $1.700^{* *}$ & 0.687 & $2.070^{* * *}$ & 0.693 \\
\hline Fast growth of private economy & 0.028 & 0.078 & $10.044^{* * * *}$ & 3.028 & $0.405^{* *}$ & 0.206 & $0.232^{* *}$ & 0.098 \\
\hline Development index $x$ fast growth & & & $-8.863^{* * * *}$ & 2.679 & & & & \\
\hline Enterprise size $x$ fast growth & & & & & $-0.092^{* *}$ & 0.047 & & \\
\hline Enterprise age $x$ fast growth & & & & & & & $-0.293^{* * * *}$ & 0.087 \\
\hline Constant & $-2.749^{* * * *}$ & 0.604 & $-1.983^{* * *}$ & 0.645 & $-2.938^{* * * *}$ & 0.611 & $-2.860^{* * * *}$ & 0.603 \\
\hline Observations & 1607 & & 1607 & & 1607 & & 1607 & \\
\hline$R^{2}$ & 0.209 & & 0.214 & & 0.210 & & 0.214 & \\
\hline
\end{tabular}

$\# p<0.10 ;{ }^{* *} p<0.05 ;{ }^{* * *} p<0.01 ;{ }^{* * * *} p<0.001$ (two-tailed test)

a negative impact on enterprise performance in all models, which differs from the findings of Li et al. (2008). This difference may come from the growing number of memberships in the CCP. In Li et al.'s study (2008), $26 \%$ of private entrepreneurs were CCP members, while in our paper, the proportion is $36.3 \%$. The reason for such a discrepancy is beyond the scope of this paper. The results further reveal that provincial GDP in 2006 shows no impact on the performance of private enterprises.

Finally, ROA was used to test the robustness, and the result is consistent with previous findings.

\section{Conclusions and discussion}

Given the data limitations, our study has some potential deficiencies that need to be improved in the future. Our data only contains cross-sectional information on the performance of private enterprises in 2007 and lacks information on enterprise performance and other relevant information in previous years. An ideal dataset 
should contain longitudinal information from 3 to 5 years or an even longer time period, which would allow for a better test of the causal relationship among variables. Despite the data limitations, we believe our study contributes to the literature in the following ways. First, our study reveals that in regions where the private economy is advanced, the competition mechanism determines the development of the private economy and the rapid growth of the private economy intensifies the competition among private enterprises and consequently inhibits the performance of private enterprises. In contrast, in regions where the private economy is relatively backward, the cognitive legitimacy of the private economy is relatively low. However, policy support becomes as strong as and even stronger than in advanced regions; hence, the improvement of sociopolitical legitimacy promotes the rapid growth of the private economy. Such improvement has a positive effect on the performance of private enterprises. The findings suggest that it may be biased to compare the developmental level of institutions statistically, and developmental pace should be taken into consideration when we examine how institutional environments impact the survival and performance of enterprises. In practice, our findings imply that governments could guide and promote private investment in less-advanced regions. This would allow private enterprises to obtain higher returns in the micro sense and would also be helpful in decreasing the gap in regional economies and promoting more equal development across regions in a macro sense.

Second, our study enriches and advances population ecology theoretically as well as empirically. Population ecology mainly applies event history analysis to examining the survival, death, and founding rates of organizations and holds that the enduring pattern of organizational change is driven by the mechanisms of legitimacy and competition. However, population ecology is poor in explicating variations in institutional environments across regions and their effect on organizational performance. Our study reveals that the two mechanisms can also be applied to explain how institutional environments in different regions impact the performance of enterprises. Along this line, future studies can test how the developmental level and pace of a certain industry in different regions affect the performance of enterprises. In most population ecology studies, the concept of population refers to industry; our study advances the concept of population from industry to ownership. Furthermore, our methodology also advances population ecology. A distinguishing feature of population ecology is the analysis of the survival and death of organizations through organizational density, measured by the number of organizations. However, this also constrains the development of population ecology. We argue that it is plausible to measure the process of legitimacy through the number of organizations; however, it is biased and particularly overlooks the competition between different types of organizations and the variation of developmental level and pace across regions. The small number of organizations in a very small economy may have high legitimacy; likewise, the growth of a certain type of organization in a rapidly rising economy may not imply improvement of legitimacy. We therefore believe that it is more reasonable to measure organizational density through the comprehensive developmental index of a certain type of organization.

Finally, our study suggests that fast-changing environments are detrimental to large enterprises; this is consistent with the theory of structural inertia for large enterprises in population ecology. We further find that fast-changing environments are beneficial 
to young enterprises and makes up for the deficiencies of the liability of newness, which ignores institutional support.

\section{Endnotes}

${ }^{1}$ An anonymous reviewer suggested we use a longer period of data to measure the growth rate of private economy. China's Statistical Yearbooks do not provide information about the number of private enterprises before 2005; thus, we could only get the average growth rate up to 3 years. We also used the 3 -year average rate in our analysis. The results are consistent with the findings presented here.

${ }^{2}$ Although our models contain two levels of variables, that is, enterprise and province, we did not adopt the hierarchic linear model (HLM) due to two reasons. First, HLM requires the sample size of the second level to be more than 50 (Hox 2002; Mass and Hox 2005), while the sample in our study has 31 provinces at the second level. Second, HLM is usually used in educational studies of students embedded within classes or psychological research on multiple tests of the same individuals. In these classic examples, students in the same class have strong mutual effects, and the results of multiple tests on the same individual are highly correlated. This violation of the independent and identically distributed (IID) requirement in OLS regression calls for the use of HLM. However, in the study of enterprises located in different provinces, the sampled enterprises from the same province do not have strong mutual effects and correlations. In fact, we refer to similar statistics analysis of enterprises within provinces, all of which used OLS regressions, such as Li et al. (2008), Du (2015), and Yang (2009).

Competing interests

The authors declare that they have no competing interests.

\section{Authors' contribution}

CZS and ZL carried out the organizational studies, participated in the sequence alignment and drafted the manuscript. All authors read and approved the final manuscript.

\section{Acknowledgements}

We thank Dingxin Zhao, Yang Cao and others who offered helpful comments in the workshop. This paper is supported by the funds of Humanities and Social Sciences in the Ministry of Education of China (12YJC840064).

\section{Author details}

'Department of Sociology, Zhejiang University, Hangzhou, China. 'Department of Sociology, Xiongzhixing Hall,

Tsinghua University, Beijing 100084, China.

Received: 27 September 2015 Accepted: 17 November 2015

Published online: 28 November 2015

\section{References}

Ahlstrom, D, and G D Bruton. 2001. Learning from successful local private firms in China: Establishing legitimacy. The Academy of Management Executive 15(4): 72-83.

Bai, Chongen, Yingjuan Du, Zhigang Tao, and Yueting Tong. 2004. Trends and determinants of local protectionism and industrial concentration (in Chinese). Economic Research Journal 4(11): 29-40

Baum, J A, and S J Mezias. 1992. Localized competition and organizational failure in the Manhattan hotel industry, 1898-1990. Administrative Science Quarterly 37: 580-604.

Baum, J A, and W W Powell. 1995. Cultivating an institutional ecology of organizations: Comment on Hannan, Carroll, Dundon, and Torres. American Sociological Review 60: 529-538.

Carroll, G R, and J Wade. 1991. Density dependence in the organizational evolution of the American brewing industry across different levels of analysis. Social Science Research 20(3): 271-302.

Carroll, G R 1985. Concentration and specialization: Dynamics of niche width in populations of organizations. American Journal of Sociology 90: 1262-1283.

Carroll, G R, and J Delacroix. 1982. Organizational mortality in the newspaper industries of Argentina and Ireland: An ecological approach. Administrative Science Quarterly 27: 169-198.

Carroll, G R, and M T Hannan. 1989. Density dependence in the evolution of populations of newspaper organizations. American Sociological Review 54: 524-541. 
Carroll, G R, and Y P Huo. 1986. Organizational task and institutional environments in ecological perspective: Findings from the local newspaper industry. American Journal of Sociology 91: 838-873.

Chan, Kam Wing, and Man Wang. 2008. Remapping China's regional inequalities, 1990-2006: A new assessment of de facto and de jure population data. Eurasian Geography and Economics 49(1): 21-55.

Covin, Jeffrey $G$, and Dennis P Slevin. 1989. Strategic management of small firms in hostile and benign environments. Strategic Management Journal 10(1): 75-87.

Du, Xingqiang. 2015. Is corporate philanthropy used as environmental misconduct dressing? Evidence from Chinese family-owned firms. Journal of Business Ethics 129: 341-361.

DiMaggio, Paul, and Walter W. Powell. 1983. The iron cage revisited: Collective rationality and institutional isomorphism in organizational fields. American Sociological Review 48(2): 147-160.

Fan, C Cindy, and Mingjie Sun. 2008. Regional inequality in China, 1978-2006. Eurasian Geography and Economics 1: 1-18.

Fan, Gang, Xiaolu Wang, and Hengpeng Zhu. 2010. China market index (in Chinese). Beijing: Economic Science Press.

Fligstein, Neil, and Luke Dauter. 2007. The sociology of markets. Annual Review of Sociology 33: 105-128.

Freeman, John, Glenn R Carroll, and Michael T Hannan. 1983. The liability of newness: Age dependence in organizational death rates. American Sociological Review 48: 692-710.

Gao, Bai. 2008. Transition in China's economic development mode and institutional school in economic sociology (in Chinese). Sociological Studies 4: 1-31.

Guo, Yi, Ying Xu, and Xin Chen. 2007. New institutionalism: Theory review and its contribution to organization studies (in Chinese). Chinese Journal of Sociology 27(1): 14-40.

Hannan, Michael T, and Glenn Carroll. 1992. Dynamics of organizational populations: Density, legitimation, and competition. New York: Oxford University Press.

Hannan, Michael T. 2005. Ecologies of organizations: Diversity and identity. Journal of Economic Perspectives 19: 51-70.

Hannan, Michael T, and John Freeman. 1977. The population ecology of organizations. American Journal of Sociology 82: 929-964.

Hannan, Michael T, and John Freeman. 1984. Structural inertia and organizational change. American Sociological Review 49: 149-164.

Hannan, Michael T, and John Freeman. 1987. The ecology of organizational founding: American labor unions, 1836-1985. American Journal of Sociology 92: 910-943.

Hannan, Michael T, and John Freeman. 1988. The ecology of organizational mortality: American labor unions, 1836-1985. American Journal of Sociology 94: 25-52.

Haveman, Heather A, and Hayagreeva Rao. 1997. Structuring a theory of moral sentiments: Institutional and organizational coevolution in the early thrift industry 1. American Journal of Sociology 102(6): 1606-1651.

Hox, Joop. 2002. Multilevel analysis: Techniques and applications. Mahwah: Erbaum.

Leibenstein, Harvey. 1976. Beyond economic man. MA: Harvard University Press.

$\mathrm{Hu}$, Xiangting, and Lu. Zhang. 2005. The influence of local protectionism on regional industrial structure (in Chinese). Economic Research Journal 2: 102-112.

Li, H. et al. 2008. Political connections, financing and firm performance: Evidence from Chinese private firms. Journal of Development Economics 87(2): 283-299.

Li, Lulu. 1998. Private enterprises in transition to the market (in Chinese). Sociological Studies 6: 87-104.

Liu, Yuzhao, and Qing Tian. 2009. How is new institutional implemented? (in Chinese). Sociological Studies 4: 133-156.

Lomi, Alessandro. 1995. The population ecology of organizational founding: Location dependence and unobserved heterogeneity. Administrative Science Quarterly 40: 111-144.

Maas, Cora J M, and Joop J. Hox. 2005. Sufficient sample sizes for multilevel modeling. Methodology 1(3): 86-92.

Marshall, Alfred. 1920. Principles of economics. London: Macmillan.

Meyer, John W, and W. Richard Scott. 1983. Organizational environments: Ritual and rationality, vol. 542. Beverly Hills, CA: Sage.

Miller, Danny, Manfred F R Kets De Vries, and Jean-Marie Toulouse. 1982. Top executive locus of control and its relationship to strategy-making, structure, and environment. Academy of Management Journal 25(2): 237-253.

Nee, Victor. 1992. Organizational dynamics of market transition: Hybrid forms, property rights, and mixed economy in China. Administrative Science Quarterly 37: 1-27.

Peng, M.W. 2000, Business strategies in transitiona economies. Thousand Oaks, CA: Sage.

Penrose, Edith. 1995. The theory of the growth of the firm. New York: Oxford University Press.

Roland, Gérard. 2004. Understanding institutional change: Fast-moving and slow-moving institutions. Studies in Comparative International Development 38(4): 109-131.

Shepherd, William G. 1986. On the core concepts of industrial economics. In Mainstreams in industrial organization, ed. H.W. De Jong and W.G. Shepherd. Dordrecht: Martinus Nijhoff Publishers.

Singh, Jitendra V, David J, Tucker, and Robert J. House. 1986. Organizational legitimacy and the liability of newness. Administrative Science Quarterly 37: 171-193.

Stinchcombe, Arthur L, and J G March. 1965. Social structure and organizations. Advances in Strategic Management 17: 229-259.

Suchman, Mark C. 1995. Managing legitimacy: Strategic and institutional approaches. Academy of Management Review 20(3): $571-610$.

Tucker, David J, J V Singh, and R J. House. 1984. The liability of newness in a population of voluntary social service organizations, Paper presented at the 49th Annual Meeting of the American Sociological Association, San Antonio, Texas.

Xin, Katherine R, and Pearce, Jone L. 1996. Guanxi: Connections as substitutes for formal institutional support. Academy of Management Journal 39: 1641-1658.

Xu, Zhaoyuan, and Li. Shantong. 2006. The trend in China's changing regional differences (in Chinese). Economic Research Journal 7: 106-116.

Yang, Chunfang. 2009. Empirical studies on the influence of Chinese enterprises' social responsibility" (in Chinese). Economists 1: 66-76.

Yang, Dian. 2011. The rises and falls in countries, capital markets and diversification strategy in China (in Chinese), Sociological Studies 6: 102-131.

Young, Alwyn. 2000. The razor's edge: Distortions and incremental reform in the People's Republic of China. The Quarterly Journal of Economics 115:1091-1135. 
Zheng, Yongnian, and Sarah Y. Tong. 2010. China and the global economic crisis. NJ: World Scientific.

Zhou, Lian. 2004. Incentives and cooperation of government officials in the game of promotion (in Chinese). Economic Research Journal 6: 33-40.

Zhou, Xueguang. 2003. Ten lectures on organizational sociology (in Chinese). Beijing: Social Sciences Academic Press (CHINA).

Zimmerman, Monica A, and Gerald J. Zeitz. 2002. Beyond survival: Achieving new venture growth by building legitimacy. Academy of Management Review 27(3): 414-431.

Zhou, Xueguang, and Wei Zhao. 2009. Researches about Chinese organizations in English literature (in Chinese). Sociological Studies 6: 145-186.

Zucker, Lynne G. 1989. Combining institutional theory and population ecology: No legitimacy, no history. American Sociological Review 54: 542-545.

\section{Submit your manuscript to a SpringerOpen ${ }^{\circ}$ journal and benefit from:}

- Convenient online submission

- Rigorous peer review

- Immediate publication on acceptance

- Open access: articles freely available online

- High visibility within the field

- Retaining the copyright to your article

Submit your next manuscript at $\boldsymbol{\nabla}$ springeropen.com 